\title{
斜方晶単一相 $\mathrm{YBa}_{2} \mathrm{Cu}_{3} \mathrm{O}_{7-y}$ 超伝導体粉末の 硝酸塩共分解法による作製
}

\author{
金井真樹・川合知二 \\ (大阪大学産業科学研究所, 567 茨木市美穂ヶ丘 8-1)
}

\section{Synthesis of Single-Phase Orthorhombic $\mathrm{YBa}_{2} \mathrm{Cu}_{3} \mathrm{O}_{7-y}$ Superconductor by Co-Decomposition of Metal Nitrates}

\author{
Masaki KANAI and Tomoji KAWAI \\ (The Institute of Scientific and Industrial Research, Osaka University, 8-1, Mihogaoka, Ibaraki-shi \\ 567) \\ Co-decomposition of the mixture of $Y, B a$, and $C u$ nitrates in the air at the atomic ratio of $Y: B a: C u=1: 2: 3$ led to \\ the formation of single-phase orthorhombic $\mathrm{YBa}_{2} \mathrm{Cu}_{3} \mathrm{O}_{7-y}$ powders, of which the sintered pellets had the superconducting \\ transition width within $1 \mathrm{~K}$. Applying $X$-ray diffraction and the resistivity measurements, this material was compared with \\ the one produced from $\mathrm{Y}_{2} \mathrm{O}_{3}, \mathrm{BaCO}_{3}$, and $\mathrm{CuO}$ by the solid state reaction.
}

[Received November 20, 1987 ; Accepted January 22, 1988]

Key-words : Superconductor, $\mathrm{YBa}_{2} \mathrm{Cu}_{3} \mathrm{O}_{7-y}$, Solid state reaction, Co-decomposition method

\section{1. 緒 言}

$90 \mathrm{~K}$ 付近に超伝導転移点 $\left(T_{\mathrm{c}}\right)$ を持つ超伝導体, $\mathrm{YBa}_{2} \mathrm{Cu}_{3} \mathrm{O}_{7-y}$ が発見されて以来 ${ }^{1)}$, この系に関して多く の研究がされてきたが, 用いられる試料の合成に関して はほとんどの場合, $\mathrm{Y}, \mathrm{Cu}$ の酸化物及び Ba の炭酸塩の 混合焼成による固体反応法が用いられてきた。この方法 は手軽であり仕込み組成が保たれやすいが，混合する時 に高い均一性を得るのが困難であるため, 単一相を得る ためには仮焼, 粉砕を繰り返すことが必要で, 試料焼成 に比較的長い時間を要する。一方， $\mathrm{Y}, \mathrm{Ba}$ ，及び $\mathrm{Cu}$ の 硝酸塩等の混合水溶液からシュウ酸, 炭酸などで金属イ オンを共沈させ，これを焼成する共沈法は2 ${ }^{213)}$ 出発原料 の高い均一性が得られるが, 液中に金属イオンが残留し やすく，沈殿した粉末の組成が変動する可能性がある. 本研究で用いた硝酸塩共分解法は, $\mathrm{Y}, \mathrm{Ba}$, 及び $\mathrm{Cu}$ の 硝酸塩混合水溶液を加熱し水分を蒸発させたのち，その まま熱分解する方法であるが, 仕込み組成が変動せず, 加熱途中イオン塩の溶融状態を通るためこの状態で十分 に攪はんすることで高均一性が得られる．われわれは硝 酸塩共分解法と固体反応法を用いて $\mathrm{Y}-\mathrm{Ba}-\mathrm{Cu}-\mathrm{O}$ 系超 伝導体を作製し， $T_{\mathrm{c}}$ 測定とX線回折により超伝導性及 び結晶構造を評価して, 焼成温度に対する依存性を調べ, 二つの超伝導体作製方法の比較を行った.

\section{2. 実 験}

\subsection{1 固体反応法}

所定比の $\mathrm{Y}_{2} \mathrm{O}_{3}(99.99 \%), \mathrm{BaCO}_{3}(99 \%)$, 及び $\mathrm{CuO}(99.9 \%)$ 粉末を乳鉢で混合, 混練し加圧成形に よりペレット化したものを空気中で焼成した. 焼成は, 約 2 時間で室温から焼成温度まで加熱し, 10 時間その 温度を保持したのち，10 時間かけて室温まで炉中で冷 却する方法をとった．焼成温度は, $800^{\circ}, 900^{\circ}, 950^{\circ}$, $1000^{\circ}$, 及び $1050^{\circ} \mathrm{C}$ である. 必要な試料については 1 気 圧酸素気流中で $880^{\circ} \mathrm{C}, 5$ 時間アニール処理を行った. 本実験は固体反応過程を調べることを目的としたため, 通常よく行われる仮焼成 $\left(800^{\circ} \sim 900^{\circ} \mathrm{C}\right)$, 粉砕なよ゙の処 理は行わなかった.

\section{1 .2 硝酸塩共分解法}

$\mathrm{Y}\left(\mathrm{NO}_{3}\right)_{3} \cdot 6 \mathrm{H}_{2} \mathrm{O}(99.9 \%), \mathrm{Ba}\left(\mathrm{NO}_{3}\right)_{2}(99 \%)$, 及び $\mathrm{Cu}\left(\mathrm{NO}_{3}\right)_{2} \cdot 3 \mathrm{H}_{2} \mathrm{O}(99 \%)$ を, $\mathrm{Y}: \mathrm{Ba}: \mathrm{Cu}=1: 2: 3$ の比 率で科量し, 水に溶解して混合水溶液 $(3 \mathrm{mmol} / \mathrm{l})$ を 作製した.これを観はんしながら加熱し, 水分を蒸発さ せ, 次に $50^{\circ} \mathrm{C}$ まで温度をあげ, 溶融状態になったとこ

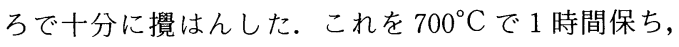
得られた粉末をペレット化し空気中で 10 時間焼成した。 焼成温度は， $900^{\circ}, 950^{\circ}$ ，及び $1000^{\circ} \mathrm{C}$ である。また焼 成処理時間を短くした $950^{\circ} \mathrm{C} ， 30$ 分間焼成試料も作製 した．焼成は，固体反応法と同じく約 2 時間で室温から 焼成温度まで加熱し，所定の時間その温度を保持したの ち，10 時間かけて室温まで炉中で冷却する方法をとっ た.一方アニールの効果を見るために，冷却速度の異な 
る炬で $950^{\circ} \mathrm{C}, 10$ 時間保持した後， 3 時間で室温まで炉 冷した試料も作製した，必要に応じこれらの試料を 1 気 圧酸素気流中で $850^{\circ} \mathrm{C} ， 5$ 時間アニール処理した。

\section{2 物性評価}

銀ペースト（藤倉化成 D-753）を用いてペレット状 試料に銅リード線をとりつけ，標準の四端子法により抵 抗一温度曲線の測定を行った，抵抗測定の精度は，10 $10^{-6}$ $\Omega \cdot \mathrm{cm}$ である，温度測定は，NBS 校正済みのゲルマニ ウムセンサーを用いた．粉末 X線回折はペレット試料を 乳鉢で粉砕し, RAD-RB system (理学電機) を用いて $\mathrm{Cu} K \alpha$ 線で測定した.

\section{3. 結 果}

\section{1 固体反応法}

固体反応法で作製した試料の超伝導特性及びX線回折 パターンの焼成温度依存性を図 1 及び図 2 に示す。 $800^{\circ} \mathrm{C}$ 加熱処理試料では抵抗測定で $4 \mathrm{~K}$ までゼロ抵抗に ならず，超伝導を示さない，X線回折パターンには，原

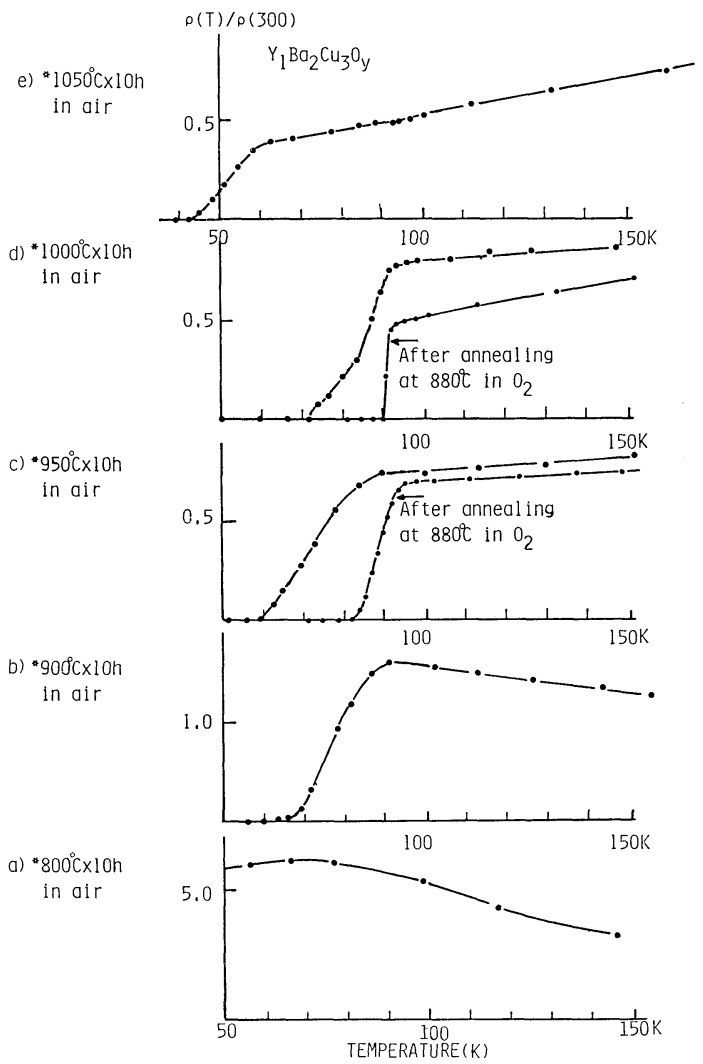

Fig. 1. Dependence of resistivity-temperature curves for $\mathrm{Y}-\mathrm{Ba}-\mathrm{Cu}-\mathrm{O}$ samples on the sintering temperature. Samples were prepared by the solid state reaction method and sintered at $800^{\circ}, 900^{\circ}, 950^{\circ}, 1000^{\circ}$, and $1050^{\circ} \mathrm{C}$ for 10 hours. The resistivity is normalized by $\rho$ (resistivity) at $300 \mathrm{~K}$.
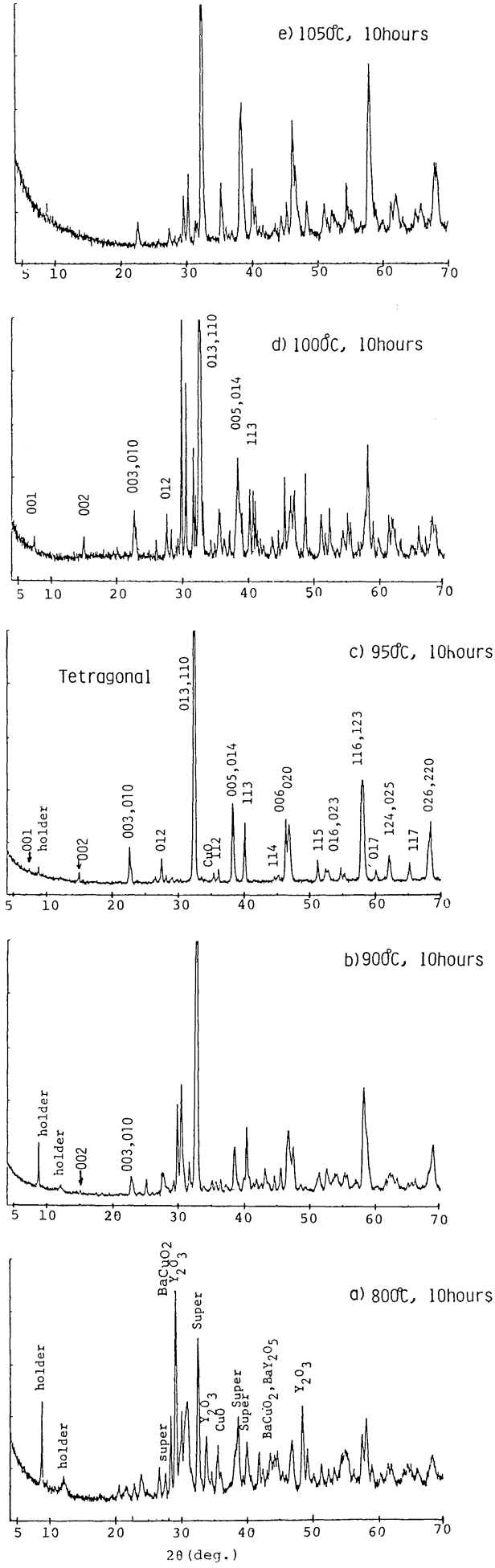

Fig. 2. Dependence of X-ray diffraction pattern for $\mathrm{Y}-\mathrm{Ba}-\mathrm{Cu}-\mathrm{O}$ samples on the sintering temperature. $\mathrm{Cu} K \alpha$ is used as an X-ray source. Samples were prepared by the solid state reaction method and sintered at $800^{\circ}, 900^{\circ}, 950^{\circ}, 1000^{\circ}$, and $1050^{\circ} \mathrm{C}$ for 10 hours. 
料の $\mathrm{Y}_{2} \mathrm{O}_{3}\left(2 \theta=29.2^{\circ},(100), 2 \theta=33.8^{\circ}\right.$, (400) etc), $\mathrm{CuO}\left(2 \theta=35.6^{\circ},(111)\right)$ 及び $\mathrm{BaCuO}_{2}\left(2 \theta=29.3^{\circ}\right.$, (600), $2 \theta=40.0^{\circ}$, (811) etc) 等のピークが見られ, 固体反応が十分進行していないことがわかる. $900^{\circ} \mathrm{C}$ 処 理でも, X線回折パターンに原料の $\mathrm{Y}_{2} \mathrm{O}_{3}\left(29.2^{\circ}\right.$, (100)) もしくは $\mathrm{BaCuO}_{2}\left(29.3^{\circ}\right.$ ，(600)) と推定されるピーク が残っており, $2 \theta=30^{\circ}$ 付近にも $\mathrm{YBa}_{2} \mathrm{Cu}_{3} \mathrm{O}_{7-y}$ 構造と 異なる相 (以下, 異相と呼ぶ）のピークが見られる.こ の試料は $90 \mathrm{~K}$ 付近より抵抗の低下が見られ，60Kでゼ 口抵抗にはなるものの, 常伝導状態の抵抗は低温になる ほど増加し金属的ではない。これに対し $950^{\circ} \mathrm{C}$ 焼成で は常伝導状態での抵抗が低温になるほど減少し金属的で あり，X線回折パターンでも残留した原料ピーク $\left(\mathrm{Y}_{2} \mathrm{O}_{3}\right.$ 等) や他の相のピークがほとんど見られず, $\mathrm{YBa}_{2} \mathrm{Cu}_{3} \mathrm{O}_{7-y}$ のパターン ${ }^{4), 5)}$ を示すが, $2 \theta=27.8^{\circ}$ 付近 の (102), (012)，あるいは $32.7^{\circ}$ 付近の (103), (013) のピーク分裂が明確でなく，正方晶が主であることがわ かる.これに対応し転移幅も， $90 \mathrm{~K}$ から $60 \mathrm{~K}$ にわたる. この試料は酸素アニール処理をする事でより鋭い転移を
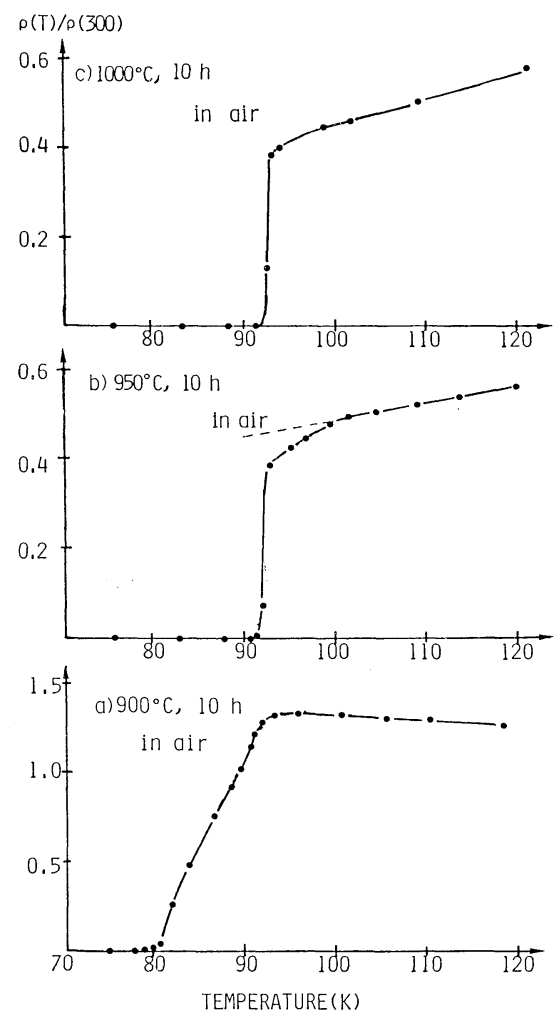

Fig. 3. Dependence of resistivity-temperature curves for $\mathrm{Y}-\mathrm{Ba}-\mathrm{Cu}-\mathrm{O}$ samples on the sintering temperature. Samples were prepared by the co-decomposition method from nitrates and sintered at $900^{\circ}, 950^{\circ}$, and $1000^{\circ} \mathrm{C}$ for 10 hours. The resistivity is normalized by $\rho$ (resistivity) at $300 \mathrm{~K}$.
見せるようになった $\left(T_{\mathrm{c}}{ }^{\text {end }}=82 \mathrm{~K}\right.$, 図 $1(\mathrm{~d})$ 参照).

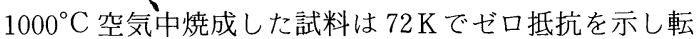
移幅は約 $20 \mathrm{~K}$ であり，950 $\mathrm{C}$ 処理に比べより狭い転移 を示したが $T_{\mathrm{c}}$ カーブが二段になっており第二相の存在 を示し，X線回折の結果も分解によると思われる異相の 存在を示している。この試料も $950^{\circ} \mathrm{C}$ 焼成の試料と同
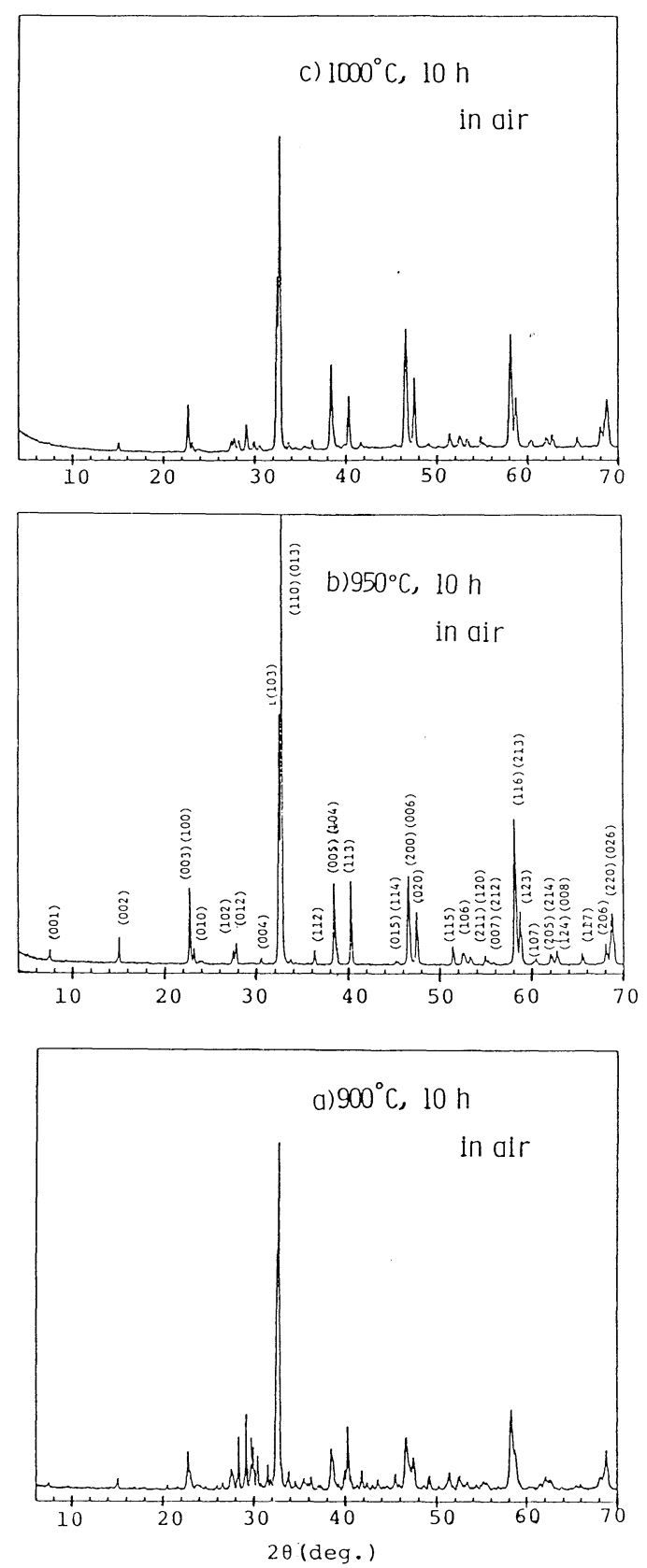

Fig. 4. Dependence of X-ray diffraction pattern for $\mathrm{Y}-\mathrm{Ba}-\mathrm{Cu}-\mathrm{O}$ samples on the sintering temperature. Samples were prepared by the co-decomposition method from nitrates and sintered at $900^{\circ}, 950^{\circ}$, and $1000^{\circ} \mathrm{C}$ for 10 hours. 
様, 酸素アニール処理により特性が改善され転移幅は約 $2 \mathrm{~K}, 90 \mathrm{~K}$ でゼロ抵抗を示した. $1050^{\circ} \mathrm{C}$ に焼成温度を上 げると異相のピークが一層増加し $1000^{\circ} \mathrm{C}$ 付近からそれ 以上で分解の始まることがわかる．この $1050^{\circ} \mathrm{C}$ 焼成試 料の $T_{\mathrm{c}}$ は $40 \mathrm{~K}$ 付近であった.

\section{2 硝酸塩共分解法}

硝酸塩共分解法で空気中 10 時間焼成した試料の抵抗一 温度曲線と $X$ 線回折パターンを図 3 及び図 4 に示す. $900^{\circ} \mathrm{C}$ 焼成では, $\mathrm{Y}_{2} \mathrm{O}_{3}\left(2 \theta=29.2^{\circ},(100)\right)$ もしくは $\mathrm{BaCuO}_{2}\left(2 \theta=29.3^{\circ},(600)\right)$ の回折ピークや,未知物 質のピーク等が認められ, 転移幅も $90 \mathrm{~K} \sim 75 \mathrm{~K}$ と広い. これに対し， $950^{\circ} \mathrm{C}$ 焼成ではX線回折パターンにおいて 異相のピークがまったく見られず， $2 \theta=27.6^{\circ}$ の (102) と $2 \theta=27.9^{\circ}$ の (012), 及び $2 \theta=32.6^{\circ}$ の (103) と $2 \theta=27.8^{\circ}$ の (013) 等の斜方晶のピーク分裂4),5)がきわ めて明確であった。この試料では抵抗の温度変化は金属 的で, $100 \mathrm{~K}$ 付近から徐々に抵抗が減少しはじめ, 92.5 $\mathrm{K}$ で鋭い超伝導転移を示した. 転移幅は $\Delta T_{\mathrm{c}}=1 \mathrm{~K}$ 程度 であった.この試料は固体反応法による試料と大きく異 なり, 酸素アニールした後も $T_{\mathrm{c}}$ の変化はほとんどなく, $\Delta T_{\mathrm{c}}=1 \mathrm{~K}$ を保っていた. $1000^{\circ} \mathrm{C}$ 焼成の試料でも同様に 転移は鋭く $\left(T_{\mathrm{c}}{ }^{\text {end }}=92.0 \mathrm{~K}, \Delta T_{\mathrm{c}}=1 \mathrm{~K}\right)$ 斜方晶のピー ク分裂ははっきりしているが，すでにわずかではあるが $2 \theta=30^{\circ}$ 付近に異相に由来するピークが認められ, 分解 が始まっていることがわかる，興味あることに硝酸塩共 分解法で作製した試料では，焼成時間の極端に短い $950^{\circ} \mathrm{C}, 30$ 分処理でも，あまりシャープではないが斜方 晶の分裂がすでに見られ，また異相のピークはほとんど 見られなかった（図 5 ). 固体反応法では 30 分焼成では まったく不十分であり，この硝酸塩共分解法では原料が 均一に分布していることがわかる. また，冷却速度の速

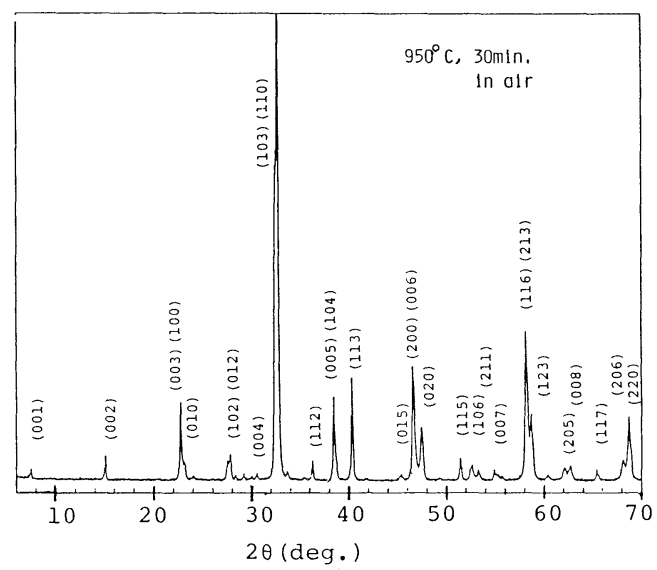

Fig.5. X-ray diffraction pattern for the $\mathrm{Y}-\mathrm{Ba}-\mathrm{Cu}-\mathrm{O}$ ( $\mathrm{Y}: \mathrm{Ba}: \mathrm{Cu}=1: 2: 3$ ) sample made by the codecomposition method after annealing at $950^{\circ} \mathrm{C}$ in air for only 30 minutes.
い 3 時間炉冷した試料も, 10 時間炉冷の試料と $T_{\mathrm{c}}$ 及び X線回折パターンに大きな変化はなかった.

\section{4. 考 察}

固体反応法による試料でも, 硝酸塩共分解法による試 料でも X 線回折測定と $T_{\mathrm{c}}$ 測定の結果は良く対応してい る. 即ち, $\mathrm{YBa}_{2} \mathrm{Cu}_{3} \mathrm{O}_{7-y}$ 構造と異なる異相の存在する 試料は $T_{\mathrm{c}}$ が低いか，または転移幅が広い。異相があま り見られない試料では, 斜方晶のピーク分裂 $(2 \theta=$ $27.8^{\circ}$ の (102)，(012）等）が明確なものがより鋭い転 移を示した．焼成温度に対する超伝導特性，X線回折パ ターンの依存性を見ると, 両方法とも, 適正な熱処理温 度領域が比較的狭いことがわかる，10 時間焼成では $950^{\circ} \mathrm{C}$ 付近が最適で, $900^{\circ} \mathrm{C}$ 以下では反応が十分に進ま ず, $1000^{\circ} \mathrm{C}$ 以上では分解が始まる. また固体反応法では, 酸素中で十分なアニール処理をしない場合に正方晶がで きやすく，酸素アニールによって転移幅が狭くなる。一 方, 硝酸塩共分解法では, 特別なアニール処理をしなく ても斜方晶単一相で, 転移幅の狭い良質な試料を得るこ とができ，これは大きな特徴である．また， 30 分とい う短時間の焼成で出発原料相が消え異相のない $\mathrm{YBa}_{2} \mathrm{Cu}_{3} \mathrm{O}_{7-y}$ 相となることは原料の均一性の高さを示 しているものと思われる. 硝酸銅は $200^{\circ} \mathrm{C}$ 以下, 硝酸 イットリウムは $500^{\circ} \mathrm{C}$ 付近でそれぞれ分解するが, $700^{\circ} \mathrm{C}$ までの温度で作製した原料には硝酸バリウムが 残っている. 硝酸塩共分解法で斜方晶単一相が比較的容 易に得られた理由としては, ペレット作製の段階で残っ ているこの $\mathrm{Ba}$ 硝酸塩が焼成の際熱分解して $\mathrm{NO}_{2}$ を発 生し,これが試料の酸化に寄与し, 酸素中アニールに近 い効果を持っているのか，あるいはこの試料で酸素の交 換が起こりやすいなどの可能性を考えており，今後の課 題である. また, マイスナ一効果については, 液体窒素 温度における磁石片（TDK，エポレック $1500 \mathrm{G}$ ) の浮 上を確認しているが，製法による違いに関する定量的な 議論は検討中である.

\section{5. 結 論}

（1）硝酸塩共分解法により, 斜方晶単一相の $\mathrm{YBa}_{2} \mathrm{Cu}_{3} \mathrm{O}_{7-y}$ 超伝導体が得られた.

（2）この試料の $T_{\mathrm{c}}$ は, $T_{\mathrm{c}}{ }^{\text {end }}=92.0 \mathrm{~K}$ で転移幅は約 $1 \mathrm{~K}$ 以内におさまっており, $950^{\circ} \mathrm{C}$ 焼成試料では $100 \mathrm{~K}$ 付近から緩やかな抵抗の減少がみられた.

（3）固体反応法では，良質試料を得るためには酸素 アニール処理が必須であるが，硝酸塩分解法ではこれが 不用であり, 仕込み組成の変動もほとんどなく, また非 常に短い焼成時間でもほぼ単一の試料が得られた。

（4）固体反応法, 硝酸塩共分解法とも単一相を生成 するには, $950^{\circ} \mathrm{C}$ 付近に狭い最適焼成温度領域がある. 
$900^{\circ} \mathrm{C}$ 以下では未反応物が残り, $1000^{\circ} \mathrm{C}$ 以上では分解 が始まる。

謝 辞 $T_{\mathrm{c}}$ 測定でお世話になった, 大阪大学産業科学研究 所高機能極限材料研究センターの宮本欽生助教授, 谷畑公昭技 官に感謝いたします。また適切なご助言をいただいた河合七雄 教授に感謝致します.

\section{文 献}

1) M.K. Wu, J.R. Ashburn, C.J. Torng, P.H. Hor,
R. L. Meng, L. Gao, Z. J. Huang, Y. Q. Wang and C. W. Chu, Phys. Rev. Lett., 58, 908 (1987).

2) K. Kaneko, H. Ihara, M. Hirabayasi, N. Terada and K. Senzaki, Jpn. J. Appl. Phys., 26, L734 (1987).

3) T. Kawai and M. Kanai, Jpn. J. Appl. Phys., 26, L736 (1987).

4) E. Takayama-Muromachi, Y. Uchida, Y. Matsui and K. Kato, Jpn. J. Appl. Phys., 26, L476 (1987).

5) M. Oda, T. Murakami, Y. Enomoto and M. Suzuki, Jpn. J. Appl. Phys., 26, L804 (1987). 